\title{
PENGETAHUAN, PERILAKU DAN LINGKUNGAN YANG BERHUBUNGAN DENGAN KEJADIAN KECACINGAN ANAK DI TEMPAT PEMBUANGAN AKHIR BAKUNG
}

\author{
Lasmarita Sinaga ${ }^{1)}$
}

\begin{abstract}
Abstrak
Kecacingan masih sering dijumpai di seluruh wilayah Indonesia. Data World Health Organization (WHO) pada tahun 2015 lebih dari 1,5 miliar orang, atau 24\% dari populasi dunia, terinfeksi cacing. Tujuan penelitian mengetahui hubungan pengetahuan, perilaku dan lingkungan dengan kejadian kecacingan anak di Tempat Pembuangan Akhir Bakung tahun 2017.

Penelitian ini menggunakan Rancangan Cross Sectional (potong lintang), bertujuan mengetahui hubungan dua variabel yaitu variabel bebas dan variebel terikat. Tempat penelitian di Pembuangan Akhir Bakung dilakukan pada bulan Mei - Juni 2017. Populasi dalam penelitian ini adalah seluruh anak pemulung sampah berusia $1-12$ tahun yang bermukim di TPA Bakung sebanyak 55 orang.

Hasil penelitian melaporkan $89.9 \%$ anak berusia $1-12$ tahun yang bermukim di TPA Bakung positif terinfeksi cacing. Hasil uji chi-square diperoleh tidak ada hubungan antara pengetahuan anak dengan kejadian kecacingan $(\mathrm{p}=0.23)$, tidak ada hubungan antara perilaku anak dengan kejadian kecacingan $(\mathrm{p}=0.674)$ ada hubungan antara lingkungan anak dengan kejadian kecacingan $(\mathrm{p}=0.000)$.
\end{abstract}

Kata Kunci : Kecacingan, Pengetahuan, Perilaku, Lingkungan

1) Alumni Prodi D4 Kesehatan Lingkungan Poltekkes Tanjungkarang

\section{PENDAHULUAN}

Kecacingan masih sering dijumpai di seluruh wilayah Indonesia dan masih dianggap sebagai hal yang sepele serta kurang mendapat perhatian oleh masyarakt Indonesia. Padahal penyakit kecacingan memiliki dampak yang panjang yang menimbulkan kerugian yang cukup besar bagi penderita. Dampak yang ditimbulkan seperti kekurangan gizi, gangguan tumbuh kembang dan gangguan kognitif pada anak. Selain itu infeksi kecacingan dapat meningkatkan kerentanan terhadap penyakit penting lainnya seperti malaria, TBC, diare dan anemia (Supali, 2008). Infeksi kecacingan umumnya menyerang anak-anak karena aktifitas anak yang bermain diluar rumah seperti bermain tanah, tidak mencuci tangan setelah melakukan kegiatan. Anak usia sekolah merupakan golongan masyarakat yang diharapkan dapat tumbuh menjadi sumber daya manusia yang potensial di masa yang akan datang sehingga perlu diperhatikan dan disiapkan untuk dapat tumbuh sempurna baik fisik dan intelektualnya.

Lingkungan kumuh merupakan tempat yang berpotensi untuk menyebabkan penyakit kecacingan. Penularan terjadi oleh telur dalam kotoran manusia yang pada gilirannya mencemari tanah di daerah di mana sanitasi buruk atau lingkungan yang kumuh. Berdasarkan data dari World Health Organization (WHO) pada tahun 2015 lebih dari 1,5 miliar orang, atau $24 \%$ dari populasi dunia, terinfeksi cacing Soil Transmitted seluruh dunia. Prevalensi kecacingan di Indonesia masih realtif tinggi pada tahun 2006 yaitu sebesar 32.6\% dan pada tahun 2007 mencapai $65 \%$ terutama pada golongan penduduk yang kurang mampu dari sisi ekonomi.

Penelitian Balai Litbang P2B2 Tanah Bumbu tahun 2008-2009 yang dilakukkan di Kalimantan Selatan melalui pengambilan sampel spesimen tinja pada anak Sekolah Dasar (SD) kelas $1 \mathrm{~s} / \mathrm{d} 6$ sebanyak 1.964 anak, didapatkan 451 anak (22.9\%) positif menderita kecacingan. Menurut hasil Survey Mercy Corp di Sumatera pada tahun 2006, Provinsi Lampung tercatat sebagai peringkat kedua wilayah Sumatera untuk penderita cacingan setelah Provinsi Riau. Jumlah pelajar SD di Lampung yang menderita penyakit kecacingan sangat tinggi. Dari 641 sampel siswa yang disurvei, 56,25\% anak menderita anemia dan $46.64 \%$ menderita cacingan. 
Pada tahun 2014 tercatat kasus kecacingan di Bandar Lampung yaitu Ascariasis Lumbricoides dengan jumlah kasus sebanyak 42 laki-laki dan 30 anak perempuan dengan umur 1-4 tahun, anak berumur 5-9 tahun sebanyak 36 anak laki-laki dan 29 anak perempuan, dan anak berumur 10-14 tahun sebanyak 16 anak laki-laki dan 20 anak perempuan (Dinkes Prov.Lampung, 2014). Dari hasil studi penelitian awal yang dilakukan oleh peneliti dengan jumlah 10 sampel pada anakanak pemulung yang bermukim di tempat pembuangan akhir (TPA) Bakung dengan umur 6-11 tahun didapati 90\% anak terinfeksi kecacingan.

Selain lingkungan yang kumuh, sampah juga menyebabkan infeksi kecacingan. Pengaruh sampah terhadap kesehatan secara garis besar di kelompokkan menjadi, yaitu pengaruh langsung dan tidak langsung. Pengaruh langsung terhadap kesehatan disebabkan karena adanya kontak langsung antara manusia dengan sampah tersebut. Misalnya: sampah beracun, sampah yang korosif terhadap tubuh, sampah yang karsinogen, teratogenik sedangkan pengaruh tidak langsung umumnya disebabkan oleh adanya vektor yang membawa kuman penyakit yang berkembang biak di dalam sampah kepada manusia (Adnani, $2011 ; 70$ ).

TPA Bakung yang berlokasi di Kelurahan Bakung Kecamatan Teluk Betung Barat Kota Bandar Lampung ialah satu-satunya Tempat Pembuangan Sampah di Kota Bandar Lampung dengan lahan seluas $\pm 14,1$ Ha. Dengan luas tersebut saat ini lahan yang terpakai sudah sekitar $90 \%$ dan volume produksi sampah yang terus meningkat setiap tahunnya. TPA Bakung menggunakan teknologi open dumping, sistem open dumping merupakan sistem yang hanya dibuang/ditimbun di suatu tempat tanpa ada perlakuan khusus. Pembuangan sampah secara terbuka dapat menjadi tempat perkembangan vektor penyakit (lalat, tikus, dan kecoa).

TPA merupakan tempat yang berpotensi mempengaruhi kesehatan pada para pemulung, karena di TPA tersebut banyak tumpukan sampah dari berbagai jenis sampah yang memungkinkan bakteri dan virus berkembang. Berdasarkan jenis sampah yaitu organik (dapat membusuk) dan non-organik (tidak dapat membusuk) sampah dapat menjadi media penularan berbagai penyakit.

\section{METODE}

Penelitian ini menggunakan desain cross sectional (potong lintang) yaitu suatu penelitian untuk mempelajari dinamika korelasi antara faktor-faktor resiko dengan outcame dilakukan sekaligus. Penelitian ini bertujuan mengetahui hubungan dua variabel yaitu variabel bebas (kebiasaan $\mathrm{BAB}$, kebersihan kuku, kebiasaan mencuci tangan dan memakai alas kaki) dan variebel terikat kejadian kecacingan. Variabel terikatnya adalah kejadian kecacingan. Tempat penelitian di Pembuangan Akhir Bakung. Penelitian ini dilakukan pada bulan Mei - Juni 2017. Populasi dalam penelitian ini adalah seluruh anak pemulung sampah berusia $1-12$ tahun yang bermukim di TPA Bakung sebanyak 55 orang.

\section{HASIL}

Hasil penelitian ini melaporkan kejadian cacing pada anak di TPA Bakung sebesar $89,9 \%$ dan $10,9 \%$ tidak terinfeksi. Distribusi usia anak yang terbanyak pada anak yang berusia 8 berjumlah 8 anak (14.5\%) sedangkan usia responden yang terendah pada anak yang berusia 36 bulan (1.8\%). Berdasaarkan jenis kelamin, anak yang berjenis kelamin laki-laki sebanyak 35 orang (63.6\%) sedangkan anak yang berjenis kelamin perempuan sebanyak 20 orang (36.4\%). Hasil penelitian tentang distribusi responden berdasarkan sekolah, distribusi terbanyak pada anak tidak sekolah yaitu 43,6\%, sedangkan yang lainnya sekolah antara Taman Kanak-Kanak dan Sekolah Dasar kelas 1 hingga kelas 5.

\section{Pengetahuan Anak}

Pada pengetahuan anak terdapat empat komponen meliputi tentang penyakit kecacingan, gejala kecacingan, penyebab kecacingan, dan cara pencegahan yang di tanyakan kepada 55 anak. Hasil yang didapat pengetahuan anak tidak baik sebanyak $49.1 \%$ dan $50.9 \%$ pengetahuan anak sudah baik. Wawancara ini dilakukan kepada ibu balita dan anak dengan jumlah dan pertanyaan yang sama, oleh sebab itu perbedaan pengetahuan baik dan tidak baik di dapatkan hasil yang tidak berbeda jauh. Hasil analisis bivariat hubungan antara pengetahuan anak dengan kejadian kecacingan, diperoleh bahwa proporsi kejadian kecacingan pada anak dengan pengetahuan tidak baik sebesar 27 orang (49.1\%), dan anak pengetahuan baik sebesar 22 orang (40\%). Hasil uji chi square $\left(\mathrm{X}^{2}\right)$ diperoleh $p$-value lebih 
besar dari alpha(0.23>0.05) dengan demikian Ho diterima dan Ha di tolak artinya tidak ada hubungan antara pengetahuan dengan angka kejadian kecacingan.

Tabel 1. Hubungan Pengetahuan Anak Dengan Kejadian Kecacingan

\begin{tabular}{|c|c|c|c|c|c|c|}
\hline \multirow{2}{*}{ Pengetahuan } & \multicolumn{4}{|c|}{ Kecacingan anak } & p-value & OR (CI 95\%) \\
\hline & + & $\%$ & - & $\%$ & & \\
\hline Tidak Baik & 27 & 49.1 & 0 & 0 & 0.23 & 1.213 \\
\hline Baik & 22 & 40 & 6 & 10.9 & & \\
\hline
\end{tabular}

\section{Perilaku Anak}

Pada variabel perilaku anak wawancara dilakukan kepada anak dan ibu balita dengan jumlah pertanyaan yang berbeda. Pada komponen perilaku anak terdapat tiga komponen pertanyaan mengenai perilaku mencuci tangan, kebersihan kuku, memakai alas kaki, sedangkan pada perilaku ibu balita terdapat dua komponen pertanyaan mengenai perilaku mencuci tangan dan kebersihan kuku. Adapun hasilnya sebanyak $60 \%$ anak memiliki perilaku tidak baik dan $40 \%$ perilaku anak sudah dikatakan baik.

Tabel 1. Hubungan Perilaku Anak Dengan Kejadian Kecacingan

\begin{tabular}{|c|c|c|c|c|c|c|}
\hline \multirow[b]{2}{*}{ Perilaku } & \multicolumn{4}{|c|}{ Kecacingan anak } & p-value & OR (CI 95\%) \\
\hline & + & $\%$ & - & $\%$ & & \\
\hline Tidak Baik & 30 & 54.5 & 3 & 5.5 & 0.674 & $\begin{array}{r}1.5 \\
280\end{array}$ \\
\hline Baik & 19 & 34.5 & 3 & 5.5 & & \\
\hline
\end{tabular}

Berdasarkan Tabel 1 diketahui bahwa analisis bivariat hubungan perilaku anak dengan kejadian kecacingan, diperoleh bahwa proporsi kejadian kecacingan pada anak yang memiliki perilaku tidak baik sebesar 30 orang $(54.5 \%)$ dan anak yang memiliki perilaku baik sebesar 19 orang $(34.5 \%)$. Hasil uji chi square $\left(X^{2}\right)$ diperoleh p-value lebih besar dari alpha (0.674>0.05) dengan demikian Ho diterima dan Ha di tolak artinya tidak ada hubungan antara pengetahuan dengan kejadian kecacingan.

\section{Lingkungan Anak}

Pada variabel lingkungan anak terdapat dua komponen yaitu sarana air bersih dan jamban. Pada komponen sarana air bersih terdapat beberapa syarat yang harus terpenuhi, $85.5 \%$ tempat penampungan air minum tidak dalam keadaan bersih dan tidak dikuras sekurang kurangnya seminggu sekali, $100 \%$ jarak sumber pencemar <10 m, dan $98.2 \%$ sumur gali dan sumur pompa tidak terdapat dinding seetinggi 3m kebawah. Selain dari segi sarana air bersih terdapat pula komponen konstruksi jamban. Konstruksi jamban diketahui bahwa sebanyak 98.2\% anak tidak terakses jamban, 100\% lantai yang ada tidak kedap air, $100 \%$ jarak jamban dengan sumber air bersih < $10 \mathrm{~m}$, dan $100 \%$ tidak terdapat air bersih dan sabun yang cukup. Dari beberapa komponen diatas pada variabel lingkungan anak terdapat pengelompokan menjadi baik dan tidak baik.Baik apabila anak mendapat nilai $\leq 8$ dan tidak baik $<8$. Dari sarana air bersih dan jamban maka responden dikelompokkan kedalam lingkungan anak yang tidak baik $83.6 \%$ dan $16.4 \%$ dikatakan baik.

Gambaran lingkungan pada lokasi penelitian ini didapatkan sebanyak $83.6 \%$ lingkungan tidak baik dan $16.4 \%$ lingkungan baik. Untuk mengetahui hubungan variabel lingkungan dengan kejadian kecacingan pada anak yang bermukim di Tempat Pembuangan Akhir Bakung disajikan dalam Tabel 2.

Tabel 2. Hubungan Lingkungan Anak Dengan Kejadian Kecacingan

\begin{tabular}{|c|c|c|c|c|c|c|}
\hline \multirow{2}{*}{ Lingkungan } & \multicolumn{4}{|c|}{ Kecacingan anak } & $\mathrm{p}$-value & OR (CI 95\%) \\
\hline & + & $\%$ & - & $\%$ & & \\
\hline Tidak Baik & 46 & 83.6 & 0 & 0 & 0.000 & $3.000(1.191-7.558)$ \\
\hline Baik & 3 & 5.5 & 6 & 10.9 & & \\
\hline
\end{tabular}

Dari tabel 2 diketahui bahwa hasil analisis bivariat hubungan antara lingkungan anak dengan kejadian kecacingan, diperoleh bahwa proporsi kejadian kecacingan pada anak di 
lingkungan tidak baik sebesar 46 orang $(83.6 \%)$, dan anak yang berada di lingkungan baik sebesar 3 orang (5.5\%). Hasil uji chi square $\left(\mathrm{X}^{2}\right)$ diperoleh $p$-value lebih kecil dari alpha $(0.000<0.05)$ dengan demikian Ho ditolak dan Ha di terima artinya ada hubungan antara lingkungan dengan angka kejadian cacing. Dengan adanya hubungan antara lingkungan dengan kejadian kecacingan maka terdapat pula resiko sebanyak 3 kali lebih besar bagi anak yang lingkungannya tidak baik terinfeksi kecacingan.

\section{PEMBAHASAN}

\section{Pengetahuan Anak dengan Kejadian Kecacingan}

Berdasarkan hasil distribusi frequensi tentang pengetahuan anak yang tidak baik sebesar 27 orang $(49.1 \%)$ dan pengetahuan anak yang baik sebesar 28 orang (50.9\%). Hasil uji Chi Square diperoleh p-value lebih besar dari alpha $(0.23>0,05)$ dengan demikian tidak terdapat hubungan yang bermakna antara pengetahuan dengan kejadian kecacingan.

Distribusi pengetahuan antara baik dan tidak baik didapatkan dengan hasil yang tidak jauh berbeda. Anak yang berusia $6-8$ tahun didapatkan mampu menjawab pertanyaan dengan baik, namun anak yang berumur 10-12 tahun tidak semua mampu menjawab pertanyaan dengan baik oleh sebab itu didapatkan hasil yang tidak berbeda jauh antara pengetahuan baik dan tidak baik dan tidak terdapat hubungan yang bermakna antara pengetahuan dengan kejadian kecacingan.

Rendahnya pengetahuan anak dan ibu balita menegani penyakit kecacingan, dampak kecacingan, gejala kecacingan, kebiasaan memakai alas kaki serta tidak mengetahui pencegahan kecacingan merupakan faktor terjadinya penyakit kecacingan pada anak dan balita di lingkungan Tempat Pembuangan Akhir Bakung ini. Menurut Notoatmodjo (2003), bahwa pengetahuan atau kognitif merupakan domain yang sangat penting dalam membentuk tindakan seseorang (overt behavior). Rendahnya pengetahuan berakibat pada tindakan anak dan ibu balita dalam pencegahan dan kebersihan diri. Salah satu dari enam tingkatan dalam domain kognitif yaitu memahami (comprehension) diartikan sebagai kemampuan untuk menjelaskan secara benar tentang obyek yang diketahui, dan dapat menginterpretasikan materi tersebut secara benar.
Beberapa jenis pengetahuan antara lain pengetahuan tak langsung (mediated) adalah hasil dari pengaruh interprestasi dan proses berpikir serta pengalaman-pengalaman yang lalu, apa yang diketahui dari benda-benda eksternal banyak berhubungan dengan penafsiran dan penerapan pikiran kita. Pengetahuan merupakan sesuatu yang hadir dan terwujud dalam jiwa dan pikiran sesorang dikarenakan adanya reaksi, persentuhan, dan hubungan dengan lingkungan dan alam sekitarnya. Sumber pengetahuan juga dapat diperoleh seseorang lewat berbagai macam cara salah satu diantaranya ialah pengetahuan yang bersumber dari akal adalah suatu pengetahuan yang dihasilkan dari proses belajar dan mengajar, diskusi ilimiah, pengkajian buku, pengajaran seorang guru dan sekolah. Faktorfaktor yang mempengaruhi pengetahuan seseorang antara lain pendidikan adalah proses perubahan sikap dan kode etik dari seseorang atau sekelompok orang yang matang dan juga melalui upaya pengajaran dan pelatihan, maka jelas kita dapat kerucutkan visi pendidikan yang mendidik manusia. Media yang secara khusus dirancang untuk mencapai masyarakat yang sangat luas. Jadi contoh dari media massa adalah televisi, radio, surat kabar, dan majalah. Serta informasi itu sendiri meliputi data, teks, gambar, suara, kode, program komputer, basis data.

Salam mengemukakan bahwa pengetahuan yang dimiliki manusia salah satunya adalah pengetahuan ilmu, yaitu ilmu sebagai terjemahan dari science. Ilmu dapat merupakan suatu modern berpikir secara objektif untuk menggambarkan dan memberi makna terhadap dunia faktual. Pengetahuan yang diperoleh dengan ilmu, diperolehnya melalui observasi, eksperimen, klasifikasi. Seperti bumi berputar pada porosnya, air termasuk unsur penting dalam organ tubuh manusia. Hasil pada penelitian sebelumnya didapatkan tidak ada bukti yang cukup untuk menujukan hubungan pengetahuan dengan angka kecacingan pada anak sekolah dasar di Kota Palu dengan nilai p.value > alpha (0.466>0.05). Didapatkan juga tidak ada hubungan bermakna antara tingkat pengetahuan siswa dengan kejadian kecacingan di SDN Karang 1 Wedi-Klaten dengan nilai p.value $>$ alpha $(\mathrm{p}=0.366>0.05)$.

Ibu balita yang bertempat tinggal di Tempat Pembuangan Akhir Bakung bekerja dengan waktu yang tidak tentu, waktu istirahat yang tidak dapat dipastikan serta anak yang berada di 
lingkungan bakung biasanya setelah pulang sekolah menghabiskan waktu dengan bermain atau bekerja di lingkungan bakung dengan didapatkannya hasil bahwa pengetahuan ibu balita dan anak yang masih rendah perlu dilakukannya penyuluhan oleh Puskesmas Bakung dengan waktu dan tempat yang sesuai. Penyuluhan yang dapat dilakukan pada ibu balita saat posyandu atau penyuluhan dengan cara face to face. dan penyuluhan kepada anak dapat dilakukan pada sore hari ketika anak menghabiskan waktu bermain, penyuluhan dapat berupa pemberian media leaflet untuk menarik perhatiaan anak bisa juga dengan menggunakan gambar karena ada beberapa anak yang belum mampu membaca. Penyuluhan ini dapat di lakukan juga dengan pemasangan banner di tempat yang sering dilihat oleh masyarakat setempat. Diharapkan ibu balita dan anak mendapatkan pengetahuan yang lebih karena pengetahuan merupakan dasar bagi seseorang dalam bertindak, sehingga kebiasaan ibu balita dan anak dapat menguranginya kejadian kecacingan di Tempat Pembuangan Akhir Bakung.

\section{Perilaku Anak dengan Kejadian Kecacingan}

Hasil distribusi frequensi perilaku anak yang tidak baik sebesar 33 orang (60.\%) dan perilaku anak yang baik sebesar 22 orang (40\%).Hasil uji Chi Square diperoleh $p$-value lebih besar dari alpha $(0.674>0,05)$ dengan demikian tidak terdapat hubungan yang bermakna antara perilaku dengan kejadian kecacingan. Sampel penelitian ini dengan total 55 sampel (12 balita dan 43 anak) maka hasil perilaku didapatkan melalui wawancara kepada ibu balita dan anak, ibu balita di ikutsertakan dikarenakan balita yang belum begitu banyak melakukan aktifitas sedangkan ibu balita merupakan satu-satunya orang terdekat dengan balita dalam kesehariannya, sedangkan wawancara dengan anak dilakukan secara langsung. Wawancara mengenai perilaku ibu balita dengan total 5 pertanyaan sedangkan wawancara perilaku anak dengan total 10 pertanyaan. Penilaian di lakukan berdasarkan scoring pada setiap pertanyaan, responden yang menjawab tidak di beri nilai 1 sedangkan responden yang menjawab iya di beri nilai 2 , dari hasil tersebut di dapatkan nilai tengah (mean), setelah didapatkan nilai mean penilaian di kategorikan. Untuk penilaian perilaku ini jika ibu balita menjawab dengan nilai $\leq 11$ maka pengetahuan dikatakan tidak baik sedangkan jika ibu balita mampu menjawab dengan nilai >11 maka pengetahuan dikatakan baik. Begitu juga untuk penilian terhadap anak, jika menjawab dengan nilai $\leq 23$ maka perilaku dikatakan tidak baik sedangkan jika anak mampu menjawab dengan nilai >23 maka perilaku anak dikatakan baik. Pada variabel perilaku terdapat 4 komponen pertanyaan yang di wawancarai kepada anak dan terdapat 2 komponen pertanyaan yang di wawancarai kepada ibu balita. Komponen tersebut antara lain perilaku mencuci tangan, kebersihan kuku, penggunaan alas kaki dan kebiasaan BAB.Hasil yang didapat pada anak sebanyak $49.1 \%$ anak kadang-kadang mencuci tangan sebelum makan, $60 \%$ anak tidak mencuci tangan dengan bangun setelah buang air besar dan sebanyak $41.8 \%$ anak tidak mencuci tangan sesudah bermain sedangkan $16.7 \%$ ibu tidak mencuci tangan dengan sabun sebelum makan. Sebanyak $43.6 \%$ anak kadangkadang seminggu sekali memotong kuku dan sebanyak $50 \%$ ibu seminggu sekali tidak memotong kuku balita. Sebanyak 32.7\% anak kadang-kadang menggunakan alas kaki ketika keluar rumah dan sebanyak $12.7 \%$ anak membiasakan diri buang air besar di WC/Toilet.

Perilaku seseorang terbentuk dari beberapa faktor seperti faktor biologis yaitu warisan biologis manusia sangatlah menentukan perilakunya. Menurut Wilson, perilaku sosial dibimbing oleh aturan-aturan yang sudah deprogram secara genetis dalam jiwa manusia. Program ini dikenal sebagai epigenetic rules yang mengatur perilaku manusia sejak kecenderungan menghindari incest, kemampuan memahami ekspresi wajah, sampai kepada persaingan politik. Faktor sosiopsikologis, karena manusia makhluk sosial dari proses sosial ia memperoleh beberapa karakteristik yang mempengaruhi perilakunya. Dapat di klafisikasikan dalam tiga komponen yaitu, komponen afektif, komponen kognitif dan komponen konatif. Komponen afektif merupakan aspek emosional dari faktor sosiopsikologis. Komponen kognitif adalah aspek intelektual yang berkaitan dengan apa yang diketahui manusia. Komponen konatif adalah aspek volisional yang berhubungan dengan kebiasaan dan kemauan bertindak. Komponen afektif terdiri dari motif sosiogenis, sikap dan emosi.

Bahwa pada dasarnya setiap perilaku selalu berhubungan erat dengan kebiasaan,dan tidak bisa dihilangkan,seperti kebiasaan belajar,maka 
tiap hari siswa tersebut akan melaksanakan perilaku belajar di waktu senggang/luang. Kebiasaan merupakan hasil pelaziman yang berlangsung pada waktu yang lama atau sebagai reaksi khas yang diulangi seseorang berkalikali. Menurut KBBI, kebiasaan adalah sesuatu yang biasa dikerjakan untuk melakukan tanggapan terhadap situasi tertentu yang dipelajari oleh seseorang individu yang dilakukan secara berulang-ulang untuk hal yang sama. Jika kebiasaan adalah respon dari perilaku maka respon yang didapatkan dari perbuatan yang sama tidak akan sama karena perbuatan manusia dipengaruhi oleh pengetahuan dan pengalaman hidupnya. Jadi pengetahuan pun berkaitan dengan perilaku seseorang yang kemudian menjadi kebiasaankebiasaan seseorang tersebut.

Kebiasaan anak tidak mencuci tangan dengan sabun sesudah BAB merupakan salah satu faktor terjadinya kecacingan, anak-anak paling sering terserang penyakit kecacingan karena biasanya jari-jari tangan mereka dimasukan ke dalam mulut, atau makan nasi tanpa cuci tangan, sehingga kuman atau telur cacing berpindah melalui tangan ke dalam tubuh. Cacing yang paling sering ditemui ialah cacing gelang, cacing tambang, cacing benang, cacing pita, dan cacing kremi.

Cara tersebut memang sesuai salah satu cara pencegahan infeksi cacing usus, yaitu pendidikan kebersihan dan kesehatan perorangan yang sangat penting sebagai usaha memutuskan mata rantai penularan ( $\mathrm{dkk}$, 2011). Infeksi kecacingan bisa ditularkan melalui tanah yang tercemar telur cacing dan tempat tinggal di daerah kumuh. Infeksi ini dapat terjadi melalui telur yang telah berembrio melalui jari-jari yang dimasukan ke dalam mulut ketika anak sedang bermain dengan kebiasaan seperti menggigit kuku, hal ini dikarenakan kebiasaan buruk anak yang tidak memotong kuku seminggu sekali sehingga kotoran dan telur menempel dalam kuku. Kebiasaan lain yang dapat menyebabkan terinfeksi anak oleh kecacingan yaitu kebiasaan memakai alas kaki. Kaki merupakan bagian dari tubuh kita pertama yang melakukan kontak langsung dengan tanah, selain melalui makanan yang tercemar oleh larva cacing, cacing juga masuk ketubuh manusia melalui kulit (poripori) misalnya lewat kaki anak telanjang yang menginjak larva atau telur. Maka upaya yang dapat dilakukan untuk pencegahan infeksi kecacingan yaitu membiasakan diri menggunakan alas kaki ketika beraktifitas atau berada diluar rumah. Hasil yang didapatkan lewat wawancara kepada ibu balita dan anak bahwa kebiasaan buruk tidak mencuci tangan sesudah buang air besar dengan sabun, setelah bermain serta kebersihan kuku yang tidak terjaga maka hal yang perlu dilakukan untuk mengubah perilaku yang menjadi kebiasaan anak dan ibu balita adalah dengan dilakukannya penyuluhan oleh Puskesmas Bakung, bagaimana CTPS yang baik, kebersihan kuku dan akibat dari kebiasaan yang buruk sehingga diharapkan melalui penyuluhan tersebut dapat membuka wawasan ibu balita dan anak dapat dilakukan juga dengan curah pendapat sehingga ibu dapat lebih aktif dalam memberi jawaban atau tanggapan dan diharapkan dapat merubah pola pikir dan kebiasaan ibu balita serta di lakukannya pembanguan MCK umum oleh UPT TPA Bakung disekitar Tempat Pembuangan Akhir Bakung dengan air bersih dan sabun yang cukup sehingga anak dan ibu balita diharapkan merubah perilaku dan menurunkan kejadian kecacingan di wilayah setempat.

\section{Lingkungan Anak dengan Kejadian Kecacingan}

Hasil distribusi frequensi lingkungan anak yang tidak baik sebesar 46 orang (83.6.\%) dan lingkungan anak yang baik sebesar 9 orang (16.4\%). Sampel penelitian ini dengan total 55 sampel (12 balita dan 43 anak) hasil lingkungan didapatkan melalui observasi di lingkungan responden.. Hasil uji Chi Square diperoleh $p$ value lebih besar dari alpha $(0.000<0,05)$ dengan demikian terdapat hubungan yang bermakna antara lingkungan dengan kejadian kecacingan. Artinya anak yang lingkungannya tidak baik beresiko 3 kali terkena kecacingan dari anak yang lingkungannya baik.

Observasi mengenai lingkungan dilakukan dengan lembaran checklist. Keadaan lingkungan di lihat dan di nilai dari 8 pertanyaan yang meliputi keadaan sarana air bersih dan jamban. Penilaian di lakukan berdasarkan scoring pada setiap pertanyaan, lingkungan anak dan ibu balita yang tersedia sarana air bersih dan jamban yang tidak sesuai persyaratan di beri nilai 1 sedangkan lingkungan anak dan ibu balita yang meliputi sarana air bersih dan jamban yang sesuai persyaratan di beri nilai 2, dari hasil tersebut di dapatkan nilai tengah (mean), setelah didapatkan nilai mean penilaian di kategorikan. 
Untuk penilaian lingkunganjika didapat nilai $\leq 8$ maka lingkungan dikatakan tidak baik sedangkan untuk penilaian lingkungan di dapat nilai >8 maka lingkungan dikatakan baik. Pada variabel lingkungan terdapat dua komponen yang di tanyakan kepada anak yaitu sarana air bersih, sebanyak $85.5 \%$ bak penampung air bersih tidak dalam keadaan bersih, sebanyak $100 \%$ sumber air bersih $<10 \mathrm{~m}$ dari sumber pencemar dan sebanyak $98.2 \%$ konstruksi sumur gali tidak sesuai dengan persyaratan. Pada komponen jamban di dapatkan hasil 98.2\% tidak terakses jamban, sebanyak $100 \%$ lantai tidak sesuai persyarat, sebanyak $100 \%$ sumber air bersih $<10 \mathrm{~m}$ dari jamban dan sebanyak $100 \%$ tidak terdapat air bersih dan sabun yang cukup.

Penyakit kecacingan merupakan salah satu penyakit yang berbasis lingkungan. Faktor lingkungan seperti tanah, air dan tempat pembuangan tinja tercemar oleh telur atau larva cacing. Air digunakan untuk beberapa keperluan di antaranya minum, mandi, mencuci peralatan rumah tangga, mencuci pakaian dan memasak. Air yang dikonsumsi manusia harus bersih yaitu harus bebas dari bahan pencemar kimiawi maupun biologis/bakteriologis. Anak dan ibu balita dalam keperluan air menggunakan air yang tersedia di kantor TPA, dengan menggunakan dirigen yang diangkut dan di simpan pada setiap rumah anak dan ibu balita, untuk tempat penampungan air tersebut didapatkan dalam keadaan yang tidak bersih, sedangkan untuk keperluan minum anak dan ibu balita meminum air tersebut tanpa di masak terlebih dahulu sehingga air yang didapatkan digunakan untuk kebutuhan mencuci, masak dan hingga minum. Penampungan air bersih tersebut dengan jarak pencemar $<10 \mathrm{~m}$ dikarenakan rumah ibu balita dan anak yang memang di tempat yang kumuh, didapatkan juga bahwa tempat penampungan tersebut dalam keadaan yang tidak tertutup.

Air bersih adalah air yang digunakan untuk keperluan sehari-hari yang kualitasnya memenuhi syarat kesehatan dan dapat diminum apabila telah dimasak Salah satu jenis polutan yang menyebabkan penyakit pada tubuh manusia ialah Infection agent (agen infeksius) merupakan bahan pencemar yang dapat menyebabkan gangguan kesehatan manusia (penyakit). Bahan pencemar ini berupa mikroorganisme patogen yang berasal dari excreta manusia dan hewan yang tidak dikelola dengan baik. Contoh agen adalah bakteri, virus dan parasit. Lingkungan anak yang dipenuhi dengan jutaan sampah dan kotoran manusia dapat menyebabkan anak terkena polutan Infection agent. Banyak penyebab sumber pencemaran air, tetapi secara umum dapat dikategorikan menjadi 2 (dua) yaitu sumber kontaminan langsung dan tidak langsung. Sumber langsung meliputi efluen yang keluar dari industri, TPA sampah, rumah tangga dan sebagainya. Sumber tak langsung adalah kontaminan yang memasuki badan air dari tanah, air tanah atau atmosfir berupa hujan.

Salah satu penyakit yang ditularkan melalui air yaitu Guine worn disease (dracuntiasis) disebabkan oleh cacing gelang. Mikroba yang masuk ke dalam tubuh manusia karena beberapa penyebab antara lain dari kotorannya (feses, urin). Penyediaan air bersih harus di simpan dalam tempat yang bersih dan tertutup, serta menggunakan gayung khusus untuk mengambil air, jarak antar sumber air minum dengan sumber pengotoran (tangki septik) dan tempat pembuangan sampah serta air limbah harus lebih dari 10meter (Depkes RI, 2002).

Jarak jamban dengan sumber pencemar $<10 \mathrm{~m}$ menyebabkan penularan penyakit dari beberapa vektor yang ada di sumber pencemar tersebut, sebanyak $1.8 \%$ kepemilikan jamban namun tidak sesuai dengan persyaratan antara lain tidak mencegah vektor pembawa untuk penyebar penyakit dan lingkungan sekitarnya.Jamban sehat efektif untuk memutus mata rantai penularan penyakit. Jamban sehat harus dibangun, dimiliki, dan digunakan oleh keluarga dengan penempatan (di dalam rumah atau di luar rumah yang mudah dijangkau oleh penghuni rumah). Terkait dengan lingkungan anak dan ibu balita tidak memiliki jamban sehingga anak dengan sembarangan membuang air besar dan tidak adanya sumber air bersih dan sabun disekitar jamban perlu dilakukannya pembuatan jamban sederhana untuk seluruh masyarakat di lingkungan bakung yang sesuai persyaratan antara. Dengan demikian diharapkan anak tidak terinfeksi kecacingan lewat kebiasaan buruk dan adanya jamban yang sesuai persyaratan.

\section{KESIMPULAN}

Berdasarkan hasil penelitian dan pembahasan dapat di simpulakan bahwa hasil pemeriksaan telur cacing pada feses balita dan anak menunjukan $89.9 \%$ positif ditemukan telur cacing pada feses dan $10.9 \%$ negatif atau tidak ditemukan telur cacing pada feses. Tidak 
terdapat hubungan antara pengetahuan dan perilaku dengan kejadian kecacingan pada ibu anak di Tempat Pembuangan Akhir Bakung. Terdapat hubungan anatara lingkungan dengan angka kecacingan pada anak di Tempat Pembuangan Akhir Bakung

Puskesmas Bakung untuk terus memberikan penyuluhan saat posyandu kepada ibu balita dan penyuluhan kepada anak dengan menggunakan media leaflet atau media lainnya di lingkungan Tempat Pembuangan Akhir Bakung mengenai penyakit kecacingan diantaranya penyebab kecacingan, gejala, pencegahan penyakit kecacingan serta akibat dari penyakit kecacingan, Penyuluhan lain yang dapat dilakukan ialah dengan cara curah pendapat. Penyuluhan tentang perilaku anak dan ibu balita mengenai kebiasaan mencuci tangan, menjaga kebersihan kuku dan penyuluhan tentang kualitas air bersih dan syarat jamban yang sehat. TPA Bakung untuk membangun MCK umum yang dilengkapi dengan air bersih dan sabun serta jamban sesuai persyaratan di sekitar lingkungan untuk masyarakat Tempat Pembuangan Akhir Bakung. Masyarakat sebaiknya menjaga kebersihan tempat penampungan air bersih serta menggunakan air bersih sesuai peruntukannya dan tidak buang air besar sembarangan.

\section{DAFTAR PUSTAKA}

Adnani, H. 2011. Ilmu Kesehatan Masyarakat. Jakarta: Nuha Medika

Departemen Kesehatan RI, 2002, Peraturan Menteri Kesehatan RI Nomor: 416/MENKES/PER/IX/1990 Tentang Syarat-Syarat dan Pengawasan Kualitas Air. Depkes RI. Jakarta.

Mardiana., Lestari, Enny Wahyu., Perwitasari, Dian., 2011. Faktor-faktor yang mempengaruhi Kejadian Filariasis di Indonesia. Jurnal Ekologi Kesehatan Volume 10(2) 2011, 82-92

Notoatmodjo, Seokidjo, 2003, Pendidikan dan Perilaku Kesehatan, PT.Rineka Cipta, Jakarta.

Supali, T. Dan Margono, S.S.,2009. Epidemiologi Soil Transmitted Helminths. Buku Ajar Parasitologi Kedokteran. Edisi 4. Jakarta: Balai Penerbit Fakultas Kedokteran Universitas Indonesia.

WHO, 2015, Diseases soil transmitted helminthiases Indonesian data. Tersedia (http://www.who.int/gho/neglected_diseas es/soil_transmitted_helminthiases/en/) 